\title{
Traditional retting of cassava roots in the ponds or the rivers
}

\author{
S. MOKEMIABEKA, J. DHELLOT, S. C. KOBAWILA and D. LOUEMBE* \\ *Faculté des Sciences, B.P. 69 Brazzaville, Congo; Tel: (242) 66205 72; (242) 6686931 \\ *Corresponding author; E-mail: dlouembe@laposte.net; kobawilasimon@yahoo.fr
}

\begin{abstract}
The traditional retting of cassava roots occurs in ponds or in backwaters. The medium $\mathrm{pH}$ is slightly acidic ( $\mathrm{pH}$ 5.54) and the pressure of dissolved oxygen is very low ( $\mathrm{pO} 2$ 1.96). The fermentation of cassava roots lasts for three days in the rainy season (October to April) with an average temperature of $26^{\circ} \mathrm{C}$, but it is longer, 5-6 days, in the dry season (May to September) with an average temperature of $23^{\circ} \mathrm{C}$. The fermentation with peeled roots is preferred because it favours the rapid softening of cassava roots and it allows to shorten at least one day the fermentation duration. In addition, the peeled roots after retting contain less tannin than the unpeeled roots and allow to obtain the alimentary products, fufu and kwanga which have a higher whiteness. The bitter variety of cassava roots is more used in fermentation than the sweet variety. Retted cassava dough is well preserved one to two months in account of anti-microbial compounds produced by lactic acid bacteria. The variability of characteristics of the products obtained from retted cassava roots is the reflection of several factors, including the cassava variety, the environmental conditions and the retting method.
\end{abstract}

(C) 2011 International Formulae Group. All rights reserved.

Keywords: cassava roots, retting, tannins, paste, bitter variety, soft variety.

\section{INTRODUCTION}

The cassava root (Manihot esculenta Crantz) is an important source of calories for the populations in tropical Africa and Central America with a cover of $80 \%$ of the daily calorific needs (Nartey, 1978). It contains cyanogenic compounds, mainly the linamarine and the lotaustraline which are very toxic for human (Montgomery, 1980; Dunstan et al., 1996; Butler and Kennedy, 1965; Louembe et al., 1997; Kobawila et al., 2005).

Fermentation by immersion of the cassava roots is one among traditional technologies of transformation of the cassava, allowing the detoxication of the cassava root (Malonga et al., 1993; Malonga et al., 1996; Cooke, 1978; Ikediobi et al., 1980; Gami and Treche, 1995).
In the rainy season, from october to april, where the average temperature is $26{ }^{\circ} \mathrm{C}$ (Samba-Kimbata and Mpounza, 2001), the duration of (peeled or unpeeled) cassava roots fermentation lasts for 3 to 4 days. In the dry season, from May to September, the average temperature is $23{ }^{\circ} \mathrm{C}$ and the duration of fermentation is 5 to 6 days. However, the duration of fermentation is lower by one day for the peeled cassava roots.

This study relates to the evolution of the physicochemical characteristics $(\mathrm{pH}$, dissolved oxygen pressure, temperature) in the ponds for steeping and the traditional technology of production of the cassava retted paste following an inquest near those which carry on the production and marketing activity of the retted cassava paste. 


\section{MATERIALS AND METHODS}

Vegetable material: cassava root (Manihot esculenta Crantz)

Measure of physicochemical parameters in the ponds of steeping: $\mathrm{pH}$, pressure of dissolved oxygen and temperature

The $\mathrm{pH}$ was measured using a $\mathrm{pH}$ meter of the type HI 9321 Bioblock, the pressure of oxygen with an oxymeter of the type HI 6142 Bioblock and the temperature with a probe thermometer of the type HI 9214 Bioblock.

\section{Content of tannins}

The determination of the content of tannins was realized by using the standard method for the proportioning of tannins for grains of sorghum by the official journal of EEC, with the difference that the extraction solvent used was acetone (Porter, 1989).

\section{Inquest near the producers}

The sample is made up of people carrying on the production and marketing activity of the steeped paste of cassava roots: 119 people including 69 in Brazzaville and 50 in Pointe-Noire. The data-gathering was made on the sites of investigation starting from a questionnaire and interviews of the listed population. The questions related to the traditional technology of retting of the cassava roots, the place of retting, the varieties of cassava roots and the process of production for the cassava retted paste.

\section{RESULTS AND DISCUSSION \\ Physicochemical characteristics}

The $\mathrm{pH}$ was slightly acid (pH 5,54) and dissolved oxygen pressure was very low (pO2 =1,96). They only decreased very slightly during the retting, less than one unit and half of variation. The temperature on the pond varied very little; it oscillated between 27,65 ${ }^{\circ} \mathrm{C}$ and $28,25{ }^{\circ} \mathrm{C}$.

\section{Content of tannins}

The proportioning of tannins indicated a maximum concentration of $60 \mu \mathrm{g} / \mathrm{ml}$ for the cassava flour giving the gelatinized flour (fufu) with clear colour and of $121 \mu \mathrm{g} / \mathrm{ml}$ for the gelatinized flour with dark colour. The results were the averages for three experiments.

\section{Retting of cassava roots and paste from retted cassava roots}

Fundamentally, two processes are used: fermentation with unpeeled roots and with peeled roots. The fresh root is immersed in water for fermentation during 2 to 5 days (or peeled then immersed in water). The retted tubers are withdrawn from water. They are peeled, washed and drained (or washed and drained in the case of beforehand peeled roots). The roots are then disintegrated by extraction of central fibre. The retted roots fall into clots to give the retted paste of cassava (Ongusua et al., 1983; Ngaba and Lee, 1979).

The bitter variety of cassava roots is mostly used in the production of the retted cassava paste (Table 2). Indeed, $44 \%$ of the producers use the bitter variety, against $11 \%$ for the soft variety. The two varieties are indifferently used by $45 \%$ of the producers. When the quantities of roots to be steeped are weak, the method most employed by the producers $(83.9 \%)$ is fermentation with peeled roots of cassava. However, for the retting of great quantities of cassava roots, the fermentation of unpeeled cassava roots is the most used method.

From the fermentation of the peeled roots of cassava, the products obtained with the retted paste of cassava have more whiteness than those obtained from fermentation of the unpeeled roots.

Retted paste of cassava roots obtained is put in a plastic packing $(98.32 \%)$ and preserved at free air $(64.71 \%)$ or with shelter of the sun $(33.61 \%)$ (Tables 3 and 4 ). The paste thus packed is preserved without deterioration one to two months about $77.4 \%$ of producers, even 4 months.

The alteration generally appears by a change of colouring and odour for $80.50 \%$ of producers but it is also expressed by the loss of water for $19.50 \%$ of producers. It is sometimes caused by the moulds. The bags out of nylon fibres or plastic would protect best the retted paste from external contaminations due to the insects. 


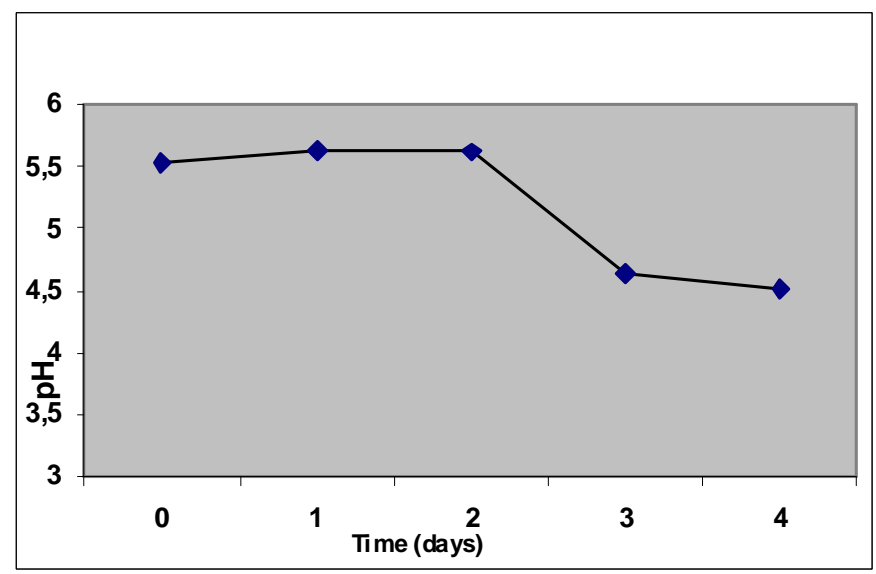

Figure 1: Evolution of $\mathrm{pH}$ in the pond during the retting of cassava roots.

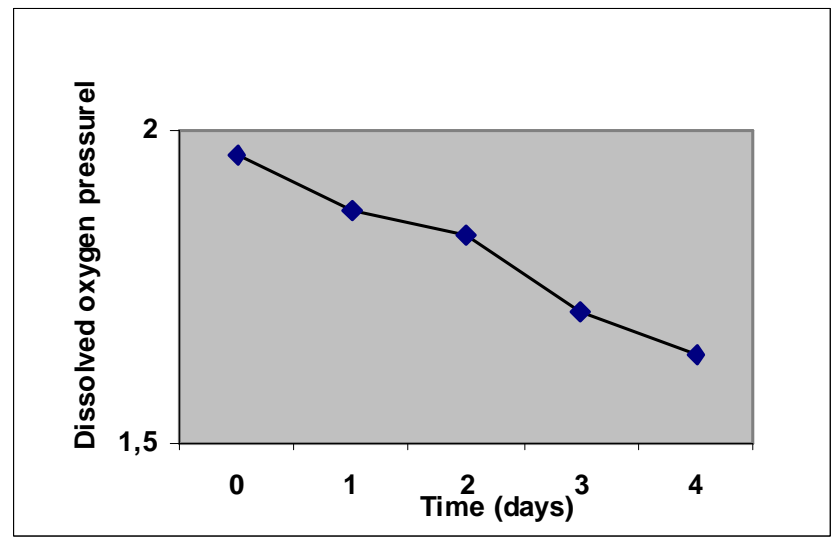

Figure 2: Evolution of dissolved pressure in the pond during the retting of cassava roots.

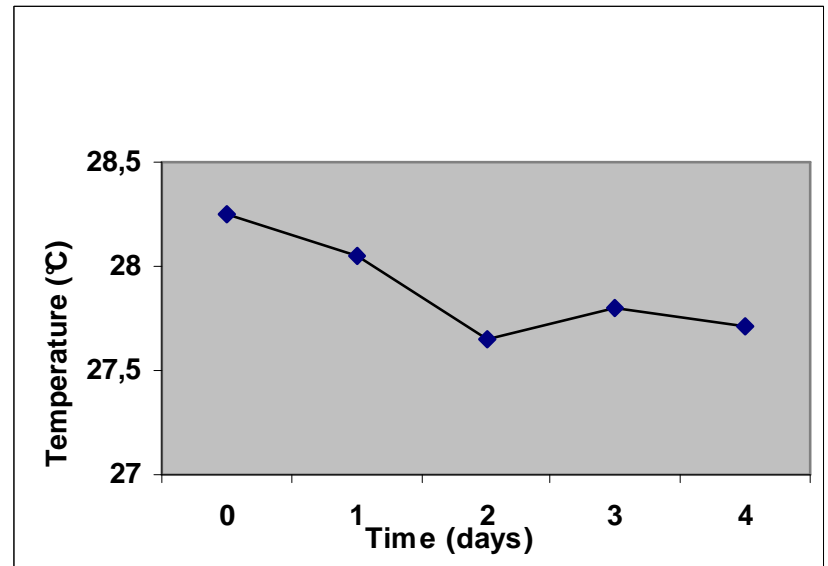

Figure 3: Evolution of the temperature in the pond during the retting of cassava roots. 


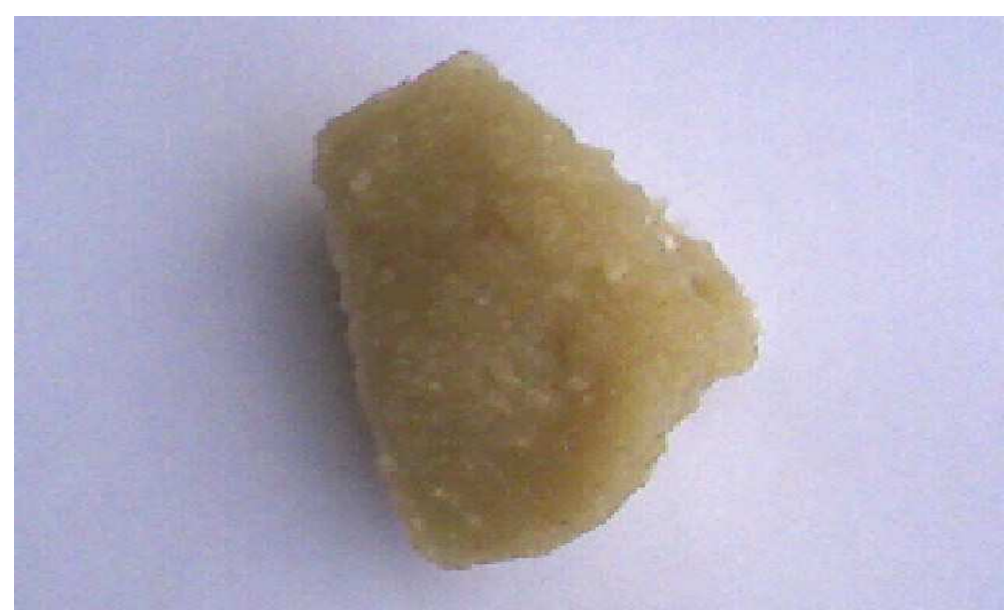

Figure 4: Gelatinized cassava flour with dark colour.

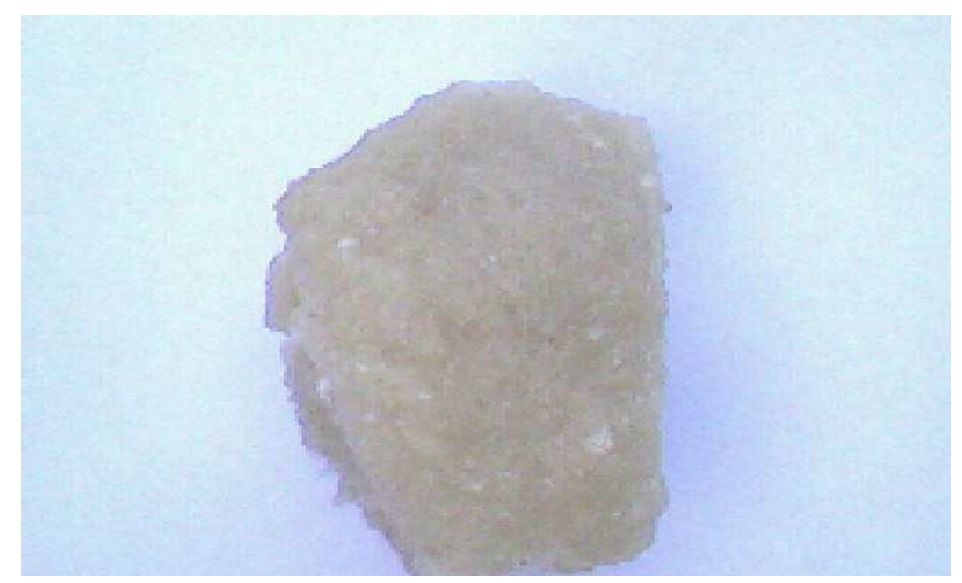

Figure 5: Gelatinized cassava flour with clear colour.

Table 1: Concentration of tannins for the samples of clear and sinks cassava flour.

\begin{tabular}{lcccc}
\hline $\begin{array}{l}\text { Number of } \\
\text { sample }\end{array}$ & $\begin{array}{c}\text { Flour of cassava } \\
\mathbf{s i n k s}\end{array}$ & $\begin{array}{c}\text { Flour of cassava } \\
\text { clear } \\
\boldsymbol{\mu g} / \mathbf{m l}\end{array}$ & $\begin{array}{c}\text { Flour of cassava } \\
\text { sinks }\end{array}$ & $\begin{array}{c}\text { Flour of } \\
\text { cassava clear }\end{array}$ \\
\hline 1 & 0 & 0 & $\boldsymbol{\mu g} / \mathbf{g}$ of flour & $\boldsymbol{\mu g} / \mathbf{g}$ of flour \\
2 & 10 & 0 & 0 & 0 \\
3 & 20 & 60 & 2,5 & 0 \\
4 & 100 & 0 & 3,3 & 15 \\
5 & 120 & 0 & 10 & 0 \\
6 & 121 & 0 & 10 & 0 \\
\hline \hline
\end{tabular}


Table 2: Variety of cassava roots used by producers for production of retted cassava paste.

\begin{tabular}{|c|c|c|}
\hline Variety of cassava roots & $\begin{array}{l}\text { Number of } \\
\text { Producers }\end{array}$ & Percent \% \\
\hline Bitter & 52 & 44 \\
\hline Soft & 13 & 11 \\
\hline \multirow[t]{2}{*}{ Bitter or soft } & 54 & 45 \\
\hline & 119 & 100 \\
\hline
\end{tabular}

Table 3: Packing of conservation of retted cassava paste.

\begin{tabular}{lcc}
\hline Packing & $\begin{array}{l}\text { Number of } \\
\text { producers }\end{array}$ & $\begin{array}{c}\text { Percent } \\
\text { \% }\end{array}$ \\
\hline Plastic packing & 117 & 98.32 \\
Jute bag & 2 & 1.68 \\
& 119 & 100 \\
\hline
\end{tabular}

Table 4: Mode of conservation of retted cassava paste.

\begin{tabular}{lcc}
\hline $\begin{array}{l}\text { Mode of } \\
\text { conservation }\end{array}$ & $\begin{array}{c}\text { Number of } \\
\text { producers }\end{array}$ & $\begin{array}{c}\text { Percent } \\
\%\end{array}$ \\
\hline Free air & 77 & 64.71 \\
Shelter from the sun & 40 & 33.61 \\
Free air or shelter & 2 & 1.68 \\
from the sun & 119 & 100 \\
\hline
\end{tabular}

Retting in ponds proceeds in weak acid and anaerobic medium, the $\mathrm{pH}$ being 4.51 and the pressure of dissolved oxygen $\left(\mathrm{pO}_{2}\right) 1.64$ at the end of the fermentation. These results are similar to those found in fermentation in artificial medium (in barrel) where the $\mathrm{pH}$ and pressure of the oxygen fall at the beginning of fermentation, medium becoming acid with a very low pressure of oxygen (Malonga et al., 1996). The retting of cassava roots is a lactic fermentation with predominance of lactic acid bacteria (Ongusua et al., 1983; Okafor et al., 1984; Oyewole and Odunfa, 1990; Meraz et al., 1992). The oscillations of temperature in the water of pond are related to the variations of the surrounding temperature and the evaporation phenomenon.

Fermentation with peeled roots is preferred because weeding before fermentation makes it possible to curtail the duration of fermentation by accelerating the process of softhening, by a fast microbial attack of the pulp of cassava (Okafor et al., 1984; Braumann et al., 1996; Okolie and Ugochukwu, 1988; Keleke, 1996). Besides, it avoids the passage of tannins from the skin of the roots into the pulp, which gives to products a strong whiteness. Indeed, the flour of cassava (fufu) obtained from the fermentation of the peeled roots did not contain tannins, except one sample, and the 
fufu (gelled mass) had a clear colour. On the other hand, the flour of cassava (fufu) obtained from the fermentation of the unpeeled roots gave a fufu of dark colour sinks and contained a very small quantity of tannins, from 2.5 to $10 \mu \mathrm{g} / \mathrm{g}$ of flour.

It thus appears that the retting allows a more or less long natural conservation of cassava roots which could deteriorate after harvest. It is an interesting characteristic; the knowledge of the factors supporting this conservation can lead to the development of natural food additives (Keleke, 1996; Ampe et al., 1995; Louembe et al., 1998; Stiles and Hastings, 1991) for the conservation of the food products against the development of the pathogenic micro-organisms or the alteration (Daeschel, 1989; Delves Broughton, 1990; Barnby-Smith, 1992; Nielsen et al., 1990; Ruiz Barba et al., 1991). The lactic acid bacteria play an important role by producing organic acids, hydrogen peroxyde, antifungal compounds and/or bacteriocin. These compounds favour the hygienic security, the storage stability and preserve the palatability (Menssens and De Vugst, 2002; Corsetti et al., 1996; De Vugst and Vandamme, 1994; Lavermicocca et al., 2000).

The bitter variety is preferred because it gives from the retted paste a product with acidulated taste, which is an organoleptic quality sought by the consumers. The soft variety gives a product with sweetened taste.

The type of river present in the production zone of the cassava retted paste determines the place of retting. Fermentation in ponds has a double advantage, especially the preexistence of the microflora of precedent rettings in the pond and the absence of water current susceptible to carry the roots being fermented in the case of the augmentation of water in the river.

The ponds or backwaters, though rare, are preferred places of retting. However, the rivers abundant and frequently met in the zone are generally used as places of retting. Thus, the great variability of the organoleptic characteristics for the products obtained from the retted paste would be the reflection of several factors, including the variety of cassava, the conditions of the medium, the method used for retting and the content of tannins.

\section{REFERENCES}

Ampe F, Keleke S, Robert H, Brauman A. 1995. The role of pectin degrading enzymes during cassava retting. In Transformation Alimentaire du Manioc, Agbor-Egbe T, Brauman A, Griffon D, Treche S (eds). Editions ORSTOM; 331344.

Barnby-Smith FM. 1992. Bacteriocins: applications in food preservation. Trends Food Sci. Technol., 3: 133-137.

Braumann A, Keleke S, Malonga M, Miambi E, Ampe F. 1996. Microbiological and biochemical characterisation of cassava retting a traditional lactic acid fermentation for Foo-foo (cassava flour) production. Applied and Environ. Microbiol., 68(8): $2854-2858$.

Butler GW, Kennedy LD. 1965. Studies on the glucosidase "linamarase". Phytochemistry, 4: 369-381.

Cooke RD. 1978. An enzymatic assay for the total cyanide content of cassava (Manihot esculenta Crantz). J. Sc. Food Agric., 29: 345-352.

Corsetti A, Gobbetti M, Smacchi E. 1996. Antibacterial activity of sourdough lactic acid bacteria :isolation of a bacteriocinlike inhibitory substance from Lactobacillus sanfrancisco C 57. Food Microbiol., 13: 447-456.

Daeschel MA. 1989. Antimicrobial substances from lactic acid bacteria for use as food preservatives. Food Technol., 43: 164167.

De Vugst L, Vandamme EJ. 1994. Bacteriocins of Lactic Acid Bacteria, 
Microbiol, Genet Appl. Blackie Acad and Professionnal: London.

Delves Broughton J. 1990. Nisin and its uses as food preservative. Food Technol., 44: $100-113$.

Dunstan WR, Henry TA, Auld SJM. 1996. Cyanogenesis in plant. The occurrence of phaseolunatin in cassava (Manihot aipi and Manihot utilissima). Proc. Roy. Doc. London, 78: 152-158.

Gami N, Treche S. 1995. Le rouissage sous terre de racines de manioc, une technique spécifique au plateau Kukuya (Congo). In Transformation Alimentaire $d u$ Manioc, Agbor-Egbe T, Braumann A, Griffon D, Treche $\mathrm{S}$ (éds). O.R.S.T.O.M : Paris.

Ikediobi C, Onyia G, Eluwah C. 1980. A rapid inexpensive enzymatic assay for total cyanide in cassava and cassava products. Agric. Biol. Chem., 44: 28032809.

Lavermicocca P, Valeria F, Evidente A, Lazzaroni S, Corsetti A, Gobbetti M. 2000. Purification and characterization of novel antifungal compounds by sourdough Lactobacillus plantarum 21 B. Applied and Environ Microbiol., 66: 4084-4090.

Keleke S. 1996. Le rouissage du manioc, contribution à l'étude du phénomène de ramollissement des racines de manioc. Thèse, Université Paris XIII, Val de Marnes, $160 \mathrm{p}$.

Kobawila SC, Louembe D, Keleke S, Hounhouigan J, Gamba C. 2005. Reduction of the cyanide content during fermentation of cassava roots and leaves to produce bikedi and ntoba mbodi, two food products from Congo. African Journal of Biotechnology, 4(7): 689-696.

Louembe D, Malonga M, Kobawila SC, Mavoungou O. 1997. Evolution de la teneur en composés cyanés des tubercules de manioc au cours du rouissage - Activité linamarasique de bactéries lactiques. MicrobiologieAliments - Nutrition, 15: 53-60.

Louembe D, Bouanga Kalou G, Malonga M. 1998. Bioconservation de la pâte de tubercules rouis de manioc. Microbiologie - Aliments - Nutrition, 16: $143-149$.

Malonga M, Mavoungou O, Kobawila SC, Louembe D, Brauman A. 1993. Les bactéries lactiques du manioc au cours $\mathrm{du}$ rouissage: caractérisation et évolution. Microbiologie-AlimentsNutrition, 11: 471-475.

Malonga M, Mavoungou O, Keleke S, Kobawila SC, Louembe D. 1996. Aspects microbiologique et biochimique du rouissage du manioc. MicrobiologieAliments-Nutrition, 14: 73-81.

Menssens W, De Vugst L. 2002. Inhibitory substances produced by Lactobacilli isolated from sourdougts. A rev. Int. J. food Microbiol., 72: 31-43.

Meraz M, Shiral K, Larralde P, Revah S. 1992. Studies on the bacterial acidification process of cassava (Manihot esculenta). J. Sc. Food Agric., 60: $457-463$.

Montgomery RD. 1980. Cyanogens. In Toxic Constituants of Plant Foodstuffs, I.E. LIENER (ed). Academic Press: New York; 143-160.

Nartey F. 1978. Manihot esculenta in Africa : Utulization as Human Food and Animals Feed. Munksgaard: Copenhagen; 42-43.

Ngaba PR, Lee JS. 1979. Fermentation of cassava (Manihot esculenta Crantz). J. Food Sci., 44: 1570 - 1571.

Nielsen JW, Dickson JS, Crouse JD. 1990. Use of a bacteriocin produced by Pediococcus acidilactici to inhibit Listeria monocytogenes associated with fresh meat. Appl. Environ. Microbiol., 56: 2142-2145.

Okafor N, Ijioma B, Oyolu C. 1984. Studies on microbiology of cassava retting for 
foo-foo production. J. Appl. Bactériol., 56: $1-13$.

Okolie PN, Ugochukwu EN. 1988. Changes in activities of cell wall degrading enzymes during fermentation of cassava (Manihot esculenta Crantz) with Citrobacter freundii. J. Sc. Food Agric., 44: 51-61.

Ongusua O, Okafor N, Onyekwere OO, Akinrele IA. 1983. Nigerian gari. In Handbook of Indigenous Fermented Foods (Vol. 9), Steinkraus KH (ed.). Marcel Dekker: Balsen, New York; 208220.

Oyewole OB, Odunfa SA. 1990. Characterisation and distribution of lactic acid bacteria in cassava fermentation during fufu production. $J$. Appl. Bacteriol., 68: 145-152.
Porter LJ. 1989. Tannins. In Methods in Plant Biochemistry (vol. 1), Plant Phenolics, Harborne JB (ed.). Academic Press: New York; 389-419.

Ruiz Barba JL, Garrido A, Jimenez Diaz R. 1991. Bacterial action of oleuropein extracted from green oliven against Lactobacillus plantarum. Lett. Appl. Microbiol., 12: 65 - 68 .

Samba-Kimbata MJ, Mpounza M. 2001. Climat. In Atlas du Congo ( $2^{\mathrm{e}}$ édn). Les Editions J.A.; $14-21$.

Stiles ME, Hastings JW. 1991. Bacteriocin production by lactic acid bacteria: potential for use in meat preservation. Trends Foods Sci. Technol., 2: 247-251. 